\title{
Correction to: Crack velocity measurements through continuous stiffness monitoring of cyclically loaded notched micro-beams of thin graded Pt-Ni-Al bond coats
}

\author{
Kaustubh Venkatraman $\mathbb{D}$ - Vikram Jayaram
}

Accepted: 1 February 2021 / Published online: 16 March 2021

(C) Springer Nature B.V. 2021

\section{Correction to:}

\section{Int J Fract}

https://doi.org/10.1007/s10704-020-00492-w

The following reference was published incorrect:

Ashwini Kumar Mishra BNJ, Aloshious L, Jayaram V (2020) Calibration of compliance with crack length: experiments on PMMA. Theor Appl Fract Mech

And should read instead:

Ashwini Kumar Mishra, Aloshious L, Jayaram V, Nagamani Jaya B (2020) The edge-notched clamped beam bend specimen as a fracture toughness test geometry. Theor Appl Fract Mech. https://doi.org/10.1016/ j.tafmec.2019.102409

The original article can be found online at https://doi.org/10. 1007/s10704-020-00492-w.

K. Venkatraman $(\varangle) \cdot$ V. Jayaram Department of Materials Engineering, Indian Institute of Science, Bangalore 560012, India

e-mail: kaustubhv@iisc.ac.in
Publisher's Note Springer Nature remains neutral with regard to jurisdictional claims in published maps and institutional affiliations. 